\title{
Financial structure of powerloom MSMEs of Ludhiana city (Punjab)
}

\author{
Garima Singh and Kanwaljit Kaur Brar
}

Received: 12.01.2018; Revised: 04.10.2018; Accepted: 18.10.2018

See end of the paper for authors' affiliations Garima Singh

Department of Apparel and Textile Science, Punjab

Agricultural University, Ludhiana (Punjab) India

Email : gsingh1505@ gmail.com
ABSTRACT : Making investment decision is a complex and dynamic process. The present study was conducted to identify the investment pattern of micro, small and medium powerloom enterprises of Ludhiana district in Punjab. The selected sample for the conducting survey through interview technique consisted of 128 MSMEs. All the micro (50 units) and medium powerloom enterprises ( 2 units) were included in the sample due to their limited total number in the list of enterprises, whereas purposive probability proportional to size sampling technique was employed to select small enterprises (76 units). Results revealed that highest percentage of the owners (71.09\%) had invested their own capital to establish their enterprises, while only 7.03 per cent MSMEs had borrowed capital from friends and relatives. The owners of medium enterprises had arranged funds from public sector banks. More than half of the total MSMEs (57.14\%) were operating through cash credit limit sanctioned by banks for buying of raw material and machinery. Only 15.38 per cent of the owners had availed Machinery Term Loan to get subsidy on new shuttle-less looms. Low enthusiasm prevailed among MSMEs to take benefit of subsidy schemes offered by the government. Profit percentage reported by majority of micro enterprises $(84.00 \%)$ was 5-10 per cent, while according to 48.68 per cent small enterprises, it was 10-15 per cent. The profit reported by medium enterprises was upto 25 per cent. The profit percentage for medium enterprises ranges from 12 to 25 per cent. Thus, an increase in profit percentage was observed with the increase in investment pattern.

KEY WORDS: Investment pattern, Micro, Small and medium enterprises

- HOW TO CITE THIS PAPER : Singh, Garima and Brar, Kanwaljit Kaur (2018). Financial structure of powerloom MSMEs of Ludhiana city (Punjab). Asian J. Home Sci., 13 (2) : 473-478, DOI: 10.15740/HAS/ AJHS/13.2/473-478. Copyright@ 2018: Hind Agri-Horticultural Society. 